PORTUGAL 


\title{
EU migrant women: migration, family life and professional trajectories
}

\section{Heloísa Perista}

CESIS-Centro de Estudos para a Intervenção Social

Av. A.A. Aguiar, 199-2 Dto. 1050-015 Lisboa (Portugal)

cesis@mail.telepac.pt

\begin{abstract}
This article focuses on the impact of migration on the career and financial autonomy of migrant women living in Portugal coming from other countries of the European Union. It illustrates the main characteristics of the employment trajectories and current situation of these migrant women, namely by identifying the migration patterns which are more prevalent in the Portuguese case than elsewhere. These may reveal a certain specificity of the EU migration to Portugal, being more in accordance with a "traditional» model of family migration, and dominated by partner-related employment reasons.
\end{abstract}

Key words: migrant women, European Union, career and financial autonomy, family histories.

Resumen. Mujeres migrantes europeas: migración, vida familiar y trayectorias profesionales

Este artículo se centra en el impacto que tiene la inmigración sobre las carreras profesionales y la autonomía finaciera de las mujeres de otros países de la Unión Europea que viven en Portugal. El trabajo ilustra las características principales de las trayectorias de empleo y la situación actual de estas mujeres, identificando un patrón de inmigración que está más presente en Portugal que en cualquier otro país europeo. Los resultados atisban una cierta especificidad del modelo migratorio intracomunitario en Portugal, asociado a un modelo «tradicional» de migraciones familiares que se explican a partir de las razones laborales del varón.

Palabras clave: mujeres emigrantes, Unión Europea, carrera profesional y autonomía financiera, historias familiares.

\section{Summary}

1. Introduction

2. Partner-related reasons versus female leaded migration

3. Working conditions in the host labour market
4. Labour and family life

5. Conclusions

References 


\section{Introduction}

This paper focuses on the impact of migration on the career and financial autonomy of migrant women living in Portugal who came from other countries of the European Union (EU) ${ }^{1}$. These EU migrant women (that is, EU nationals moving within the Community) constitute an important, and underresearched, group and its study provides a good test of the gendered nature and experience of European citizenship.

However we must stress that «it is very difficult to generalise about the effect of migration on women's career and financial autonomy, given the interaction of a whole range of life events. The motivations triggering the initial migration, together with women's employment and educational status prior to migration, have proved to be important determinants of the postmigration experience. Changes in marital status and family formation in the host State also have a substantial impact on women's labour market participation. The extent to which this reflects a lack of autonomy depends very much on domestic social policy and cultural attitudes around mothering» (Ackers, 1998: 187).

Therefore, the assumption that EU migrant women share a broad universality of status - namely with EU migrant men on the one hand- and these women are equally "privileged» on the other hand, must be questioned. Actually, the results of this study have shown how the variation in women's backgrounds in terms of social class, educational level, family status and also countries of origin and of destination as well, influence their migration experiences, namely in terms of professional career and personal autonomy.

The Portuguese case appears as a rather «atypical» one among the countries where the empirical work involving the in-depth life-histories interviews ${ }^{2}$ which are at the basis of the current analysis took place. The women interviewed in Portugal present some characteristics that distinguish them from the EU migrant women in other countries, namely in terms of their employment histories.

Considering the main motivations women gave for their initial migration, two groups are of particular interest here: those who said they moved with

1. It reports to the findings of a research project on the gender dimension of intra-Community migration and the experiences of EU migrant women which was developed by a team of academic partners in Sweden, Greece, Portugal, Ireland and the United Kingdom. The main results of this study were published in Ackers, 1998. This paper is specially based upon chapter six of this publication, "Citizenship and paid work: the impact of migration on employment status», which was written jointly by Louise Ackers and Heloísa Perista.

2. The central empirical focus of the project was on the 341 detailed life-history interviews which were done with migrant women in the five Member States. The interviews were designed to collect both quantitative and qualitative data. During the interview women were encouraged to talk about their migration history, their experiences of the migration process and its impact on: family/informal care networks; career and financial autonomy; identity (including a sense of feeling «European»); general quality of life (including experience of welfare systems); awareness and exercise of Community rights. 
career objectives in mind (to work, to study or to develop language competencies) and those who gave some partner-related explanation. In opposition to the prevalent trend among EU migrant women, EU female nationals living in Portugal present a higher proportion of women whose main reason to move was partner-related.

These different initial motivations or objectives will constitute an important element in terms of the impact of migration on women's employment trajectories. These last ones also depend on marriage and childbirth, as well as on problems of recognition of qualifications, etc., together with new opportunities and the development of career status and autonomy.

The nationality of the women and the economic situation of the sending and receiving countries also has an important effect. In general, women from Southern countries, namely from Portugal and Spain, who migrated for employment-related reasons benefited from the move to an area where employment prospects are better. "Many other women were not so much influenced by «push» factors encouraging them to leave their home State as the lure of new opportunities elsewhere, which often meant they could utilise their skills to maximum effect in the host labour market» (Ackers, 1998: 189-90).

The following will thus try to highlight the interaction of these diverse and complex dimensions to be considered in terms of the impact of migration experience on EU women's employment trajectories, focusing on the particularities of the Portuguese case.

\section{Partner-related reasons versus female leaded migration}

Most EU migrant women who are living in Portugal cited her partner as the main reason for their migration. Some forty-five women $(60 \%)$ claim that their coming to Portugal was due to partner's related reasons. Of these, nineteen $(25 \%)$ refer to the partner career, in terms of increased job opportunities for him.

The family came to Portugal due to a good job opportunity for the husband $(\mathrm{D} 300)^{3}$.

Came to Portugal two years ago, because of her husband's job. «I usually follow him, but he always asks me if I want to go» (D306).

Her husband works as a hotel director and every time he wants to progress in his career he has to move to a greater hotel in another town or in another country but always belonging to the same French economic group. That's why they came to Portugal: here there was a job opportunity for her husband and Portugal is an EU country, not so far from France (D337).

3. Those codes were given for interviewees during the project, in order to assure anonymity. 
This migration pattern is more prevalent in the Portuguese case than elsewhere which may reveal a certain specificity of the EU migration to Portugal, being more in accordance with a "traditional» model of family migration, and dominated by partner-related reasons.

In most cases, Portugal was not chosen by the woman as an emigration country. Quite often, their coming to Portugal was even decided by the husband's company.

She came here because her husband was sent to Portugal to work (D311).

They did not choose the country. It was her husband's company that sent him here (D322).

She came to Portugal 16 years ago «because my husband was sent here by his firm to direct the Portuguese branch» (D356).

In other cases the decision of coming to Portugal was a husband's choice. This is particularly frequent when the partner is Portuguese (or at least has Portuguese origins), what occurs in eighteen cases. Generally the decision of coming/returning to Portugal is up to the partner, and the woman follows him.

Came to Portugal ten years ago (1985) with her ex-husband. «I didn't choose to come to Portugal. He did» (D320).

Came to Portugal two years ago with her companion who is of Portuguese origins. They were already living together in France where they met. He came to Portugal because he wanted to know the country since he had always lived in France. [...] The choice to come was him (D342).

«I didn't choose Portugal. He was Portuguese so we came here» (D359).

She was born in Italy. She met her husband in Paris when they were both living there: he was a teacher at the university and she was about to finish her graduation thesis. Her husband is Portuguese and that is the reason why she came to Portugal. In 1980 he decided to come back to Portugal and she came with him (D361).

Some of these women (more precisely nine, which corresponds to $12 \%$ of all the interviewed in Portugal) joined her partner a few months later to his arrival. The woman usually stays longer in the country of origin because of the schooling of the children, but in some cases also due to personal reasons such as completing a degree.

She came to Portugal in 1993 to join her husband who was already working here for nine months. She waited for the end of the schooling year to come (D300). 
After finishing her college degree she came to join her husband who had been working here for one year (D325).

She came to Portugal five years ago to join her husband who had created an enterprise in Portugal a year ago (D333).

We may find among these women whose coming to Portugal was primarily due to partner's related reasons some who keep their professional activity after migration. In these cases, women's careers do not seem to have been affected by the migration process.

«I usually follow him, but he always asks me if I want to go.» This time she would only come if she could keep on working. Since the bank where she was working in France had a cooperation agreement with a Portuguese bank, she «was lucky to come to work to Portugal» (D306).

Came to Portugal eight years ago with her husband and two children because of her ex-husband who came to be a teacher at the French Institute in Oporto. Now she stays here because of her work both in Oporto and in Lisbon: «I like the country very much and there is a lot of opportunities in the field where I'm working. I will make a new life here, now». She works as a painter for several museums (D343).

Migrating for their own career was the case of $20 \%$ of the women interviewed in Portugal.

In this group we find either women who declare having left their country of origin to work or to study. Education, development of language competencies and employment appear quite often related in terms of the main reasons for coming to Portugal. Sometimes, a woman decides to come for a short period in order to improve their language skills and at the end she gets a job and decides to stay.

«I wanted to have a professional experience out of my country after I got my degree.» She applied for a trainee period through an international association of students and she was chosen to come to Portugal (although she preferred to go to Australia). At first, she intended to stay in Portugal for 6 months but after the trainee period she got another and another working contract and she is still here (D326).

She came alone to learn Portuguese at a Portuguese university. During her studies in her home country she had already studied Latin, Spanish and French and she wanted to learn another language studying abroad. She got a scholarship and she came to Portugal for one year. After that, she got another scholarship for another year in order to get a post-graduation. And finally she decided to stay (D327).

She came to Portugal in 1978 with a scholarship of one year while she was at the university in a course of Languages and Literature. [...] She stayed one 
year at the Faculty of Humanities and then «I stayed for another year working at the high school Rainha Dona Leonor, in Lisbon. I had met my husband at the Faculty but I still returned to France because I didn't want to make a decision about leaving my country like this. It's not an easy decision. I was in France for one year and then we decided to stay here» (D346).

Meeting a partner during a first stay in Portugal, quite often combined with work-related reasons, is one of the main reasons to turn an intended short stay in a longer, maybe permanent, one. Most of these women who migrated for their career came to Portugal alone, as single. Marriage or cohabitation comes afterwards, usually with a Portuguese man.

Came to Portugal thirty years ago (1965). [...] «The idea was to go away for two years, away from that island.» Her intention was to go back and continue her professional career, but that didn't happen because in the meantime «I got married to a Portuguese» (D308).

The case mentioned above, of a woman who migrated to work thirty years ago is an exception, since a large part of these women came to Portugal only a few years ago, in most cases during the 90's. Their decision to migrate was often influenced by the difficult situation of the labour market in their home countries.

Came to Portugal four years ago with her sister with the objective of coming here to work. There was an opportunity for them to open a beauty centre in Portugal and in France the market was completely full. «We couldn't buy there, we had to rent, and we wanted to open a real big thing» (D315).

"I like my work, the school is a good one and I've made some professional progresses. I have good friends, English and Portuguese. Besides, I have a job and in England I might not have, due to the unemployment situation» (D335).

She decided to migrate because she didn't get a place at the London Dance Company. [...] In the meanwhile she was invited by the director of the Dance National Company of Portugal to come to this country and so she came (D373).

In some cases, women came to Portugal having already a work contract, usually with a firm related to their country of origin or even with a subsidiary company.

Left her country of origin in order to work. Had a two-year contract as a school teacher at the English school in Lisbon (Carcavelos) (D308).

She came to Oporto because there was a vacancy at the German School of Oporto (D365).

«I'm very curious and in Germany I had already worked with Portugal and Spain in the export/import business and I wanted to see my work from the 
other side. It was not possible to go to Spain and they asked me if I wanted to come to Lisbon. It was an opportunity to know another culture, another language, another country. On the other hand, coming here through the firm was important in professional terms» (D374).

\section{Working conditions in the host labour market}

Being in a new country often creates difficulties to women who try to get a job. Most of these difficulties are related to their poor ability in dealing with the local language.

«It's very difficult. At the beginning I thought that I couldn't get a job because of the language. I'm waiting for an answer for three different things» (D301).

"When I came to Portugal, it was impossible to get a job in the journalism area since I didn't speak Portuguese»(D309).

Since she is in Portugal she has never had a paid job. «It would be difficult for me to get a job because of the language problems» (D340).

Unemployment is thus not uncommon. In some cases, it is only for a few months, in other for a longer period which clearly reflects on women's lack of satisfaction.

She got a job a month ago, after a whole year of unemployment. For her it was very important to get a job because «after spending a whole year at home, for me who have been working since I was eighteen, it was driving me mad» (D311).

Sometimes these women also experience difficulties in order to be able to find a job in the domain they used to work. Migration often implies a significant change in their professional lives.

She used to work as a specialised nurse. She had to stop working when she came to Portugal «because that job is not available here» (D307).

Having left her country had consequences in her professional life, «a total change. My professional project was not very clear and I'm working in an area that has nothing to do with my past. I'm not a journalist, I had no training, nor the opportunity to be a journalist in France. I learned a new job» (D310).

In other cases this «change» means a job well below their real skills. Even women who have migrated with career objectives in mind have suffered downward career mobility in some cases. Therefore, we may find several women who are working in areas for which they are substantially overqualified.

This process of deskilling is often due to the difficulties these women have to face in getting their qualifications and diplomas duly recognised in the host country. 
She is a psychologist. After being unemployed for one year, she got a job a month ago, in a tourist agency that belongs to the Spanish Tourism Bureau in Lisbon, which has nothing to do with her profession (D311).

"I do a lot of things because we have to survive. These are activities which are below my skills and I suffer with that. [...] So I must content myself with this under-employment or with jobs which I would never had taken in Belgium. [...] I'm also a victim of my education: I have a degree, several courses and good skills. But those skills are not appreciated here... well, perhaps in Belgium they also were'nt...» (D327).

"It is almost impossible to have our foreign certificates to be recognised here in Portugal» (D347).

«I thought possibilities here would be the same. The first thing I did was learning the language, a thing Spanish people never do when they come here. Then I started to send my curriculum. As I didn't have any equivalence, things started to close down for me» (D357).

She had many problems to get the recognition of her qualifications as a talk therapist and to be able to exercise her profession in Portugal (D370).

The impact of migration on women's working life is evaluated by some of them as very negative. In some cases, migration is even perceived as imposing an end to their careers.

For her it was «quite a disaster». In Spain she managed to live from her profession (she is a psychologist). She had an office and a network of patients and colleagues «I stopped doing that. It had been a great effort and it was very important for me to have achieved that. [...] All that, I lost here» (D311).

"Working was my life. [...] My life is great but I do miss my work, it's important for my mental health. I miss my work a lot» (D324).

«It took me some time to get a job. And in Spain I had a professional career, I had several things already done and I could have more perspectives. Here I don't. I'm doing a little work but I can't do no more. In that sense, this is a bit frustrating» (D333).

«It was the end of the possibility of having a career in my teaching profession. Here it's completely impossible to have a career. I have no career» (D347).

The most severe effects on women's career and financial autonomy, as a result of migration, can be seen in the cases of women with professional qualifications and who had a highly developed professional career who had migrated because of their partners. Migration may therefore be faced as a double sided process, creating difficulties for women and being beneficial for their 
husbands (as well as for the rest of the family). «The economic consequences of migration are, nevertheless, quite complex: in many cases the move has increased the financial status of the family as a whole through its impact on the partner's status and earning capacity. The decision of a household to migrate may thus appear to be «rational» in any narrow cost-benefit analysis of aggregate family income, but at the cost of increased levels of dependency and loss of personal autonomy for female partners» (Ackers, 1998: 199).

Besides these situations, where women stop working when they leave their home country, migration may also determine a break in female careers. In some cases, the years that follow the move are a period when the woman stays at home and assumes herself as housewife and mother. Other women, first experience a hard time in the new country and in the new job, and only some years after they get a more stabilised professional life.

After arriving in Portugal she stayed as a housewife until 1992 when she opened her antiques shop where she works every afternoon (D302).

The fact of migrating made her leave a job she «loved» and although she came with a job from Belgium «it was a great change and very difficult. It's also a matter of mentality and not for the fact that it's Portugal. For the first two years I nearly got back to Belgium. It was complicated at the professional level. Now I have done a career here and I'm OK» (D314).

Although the overwhelming impression from the interviews was one of career dislocation and downward career mobility some women had increased their economic status and autonomy. Having migrated represented a positive change in the professional lives of several women now living in Portugal. In some cases, these women consider that their employment situation here is better than the one they could have in their country of origin, either in terms of wages, professional responsibilities or simply because they have a job.

"Maybe if I compare, today I have a better situation than some of my colleagues back in Belgium [...] I'm better off than those of my generation, I earn well» (D320).

«In professional terms, leaving Germany was an improvement, not in economic terms -in that aspect I went backwards - but in terms of career, in terms of responsibility» (D367).

«It's fine. I got my degree in a very bad economic period specially in Spain. I was lucky for being able to go to another European country and to get a job at once. Some colleagues of mine went to unemployment when they finished their studies and they are still unemployed» (D326).

Living in Portugal opened new professional opportunities for some women, who now have better chances to accede to a wider choice of activities. 
«The advantage of being here is that we have access to lots of things the French don't have. [...] I managed to work with programs I had dreamed of and that I would have never been able to in my own country» (D313).

Having left England "was very good because I teach English and in my country it is difficult to find a job of this kind. Here there are plenty of schools for English language» (D325).

"It was important for me to come to Portugal because if I stayed here working is because of my profession. I could be earning more money than here but probably not in what I like to do: advertising. In Spain I could be working as a secretary or something else although my goal would always have been advertising. Here I like what I do» (D344).

"In Portugal there are few ballet teachers with a diploma. Here I am very requested. In England it would perhaps be up to me to look for a job, here I'm always saying no... this is a great feeling» (D373).

Another type of beneficial effect of moving has to do with self-confidence.

"I would say it was a good move. I am much more self-determined. I really look for what I want by myself» (D556).

This increasing self-confidence may be related to an interesting feature of the situation in employment of the EU migrant women living in Portugal which relates to the high percentage of these who are self-employed —around $15 \%$ have their own business, and some more give help in their husband's firms. Going into a business of their own was, in some cases, an answer to the difficulties found in getting a good job as an employee. In most cases, to create their own job was a decision positively evaluated by these women who, at present, run their own business: art gallery, clothing industry, handicraft products, estate agency...

«Because of the language problems when I tried to get normal jobs in normal firms. That would have been difficult in France, too. But when I decided to go into business by myself I think it was easy. I easily reached firm's managers, marketing managers. I spoke Portuguese very badly and I think people were very open» (D309).

She began working as a stylist when she was twenty. Neither her or her husband had much money and she decided to create clothes and to try to sell it to Portuguese factories. She worked as a free-lancer for several factories until she managed to open her own shop to sell her creations. Now she has three ateliers where she employs several women (D338).

Almost one third of the women who are currently working have teaching activities. Most of them are language teachers, quite often in a part-time basis, and some also do translation jobs; i.e., they apparently take advantage of their language 
capacity in order to improve their job opportunities. In practice, this is a specific manifestation of a wider process of deskilling, in relation to the abuse of migrant women's language skills —or particular links with their country of origin. In that sense it seems that the language skills of these women are treated by employers as simply added bonus, attracting no more status or remuneration.

Several interviewees refer to poor working conditions, in terms of wages, working hours, job security and related benefits. These problems faced by migrant women may not be envisaged apart from the overall situation in the labour market in Portugal towards an increasing precarisation and «flexibilisation", phenomena that affect mostly female labour force.

To work as an employee without any work contract or in the black economy is quite common.

In Portugal she only started working two months ago. She was unemployed for four months. She is working as an architect-urbanist at a private office. She has no contract (D330).

She has been doing some temporary jobs, painting T-shirts, decorating discos and specially making translations. These are jobs which are not declared for taxes nor social security (D339).

Other poor working conditions are referred to as well:

In Portugal she worked for two years at the English school, «more than fortyeight hours a week, there was always work to be done» (D308).

«It is not a safe job and I feel my wage is very low» (D349).

«Here for example my working time reduced from sixteen to eight hours a week. So I have to live with half of the money. There is no stability» (D359).

«I also miss holidays. I only have twenty two days of holidays and in Germany we have thirty, thirty one days» (D374).

The impact of migration on women's career and its evaluation by women thus varies a lot according to different factors. Some migrant women do not even seem to face this impact as an issue for their personal lives.

Having left her country had a big impact because she stopped working: «I had worked in banks for ten years [...] I was leaving my job because I was getting married. For me, the professional career is not very important» (D318).

\section{Labour and family life}

Marriage and family life are some of the most influential factors in terms of female professional histories. The effects of marriage are evident mostly for women who have migrated to accompany their partners. 
After the marriage she lost any job perspectives. Her husband stays so shortly in the same country that «I stay like this; I pass my time and do nothing [...] I'm waiting for being able to have a normal rhythm of labour» (D301).

She never got a job mostly due to the frequent need to move because of her husband's professional career (D332).

As one of the interviewees said:

"When the husband has a profession, it's usually the woman who sees her profession sacrificed. There is times when women get revolted because it seems that all are dippers and children and one cannot fulfil herself» (D305).

Other women do not share at all this feeling of «sacrifice», specially when they have children. Giving up work in order to care for children is faced by them as the right option to make, at least when children are in their early years.

In 1977, when her first child was born, she gave up her profession. «Having quit my job to stay with my children was the right decision to make» (D304).

Childbirth often determines a stop in women's career or at least a break of several years. These migrant women thus follow the prevalent pattern in their home countries, contrary to what usually occurs in the country where they now live. Portuguese women present a specific activity pattern in the context of the European Union since they tend to work full-time and on a continuous basis along their life cycle, even after childbirth.

She has a secretarial course and she worked as an «attachée de direction» for five years in an engineering enterprise. She stopped working when she was twenty-six because her husband asked her to and because she had her children (D300).

She had a breakdown in her professional activity while she was living in Setubal because she got pregnant and she decided not to work during her pregnancy and while her child was a small baby (D337).

In several cases, when children grow older women go back to work, usually on a part-time basis, easier to combine with family responsibilities, or with other sort of arrangements: working at home, choosing particular jobs...

In 1972 her daughter was born and she stopped working. In 1976 she went back to work, working part-time as a house visitor (D307).

«I've put my children before my career. I like my work (she is a mathematics teacher) and my career never developed a lot because it demanded more availability than the one I could give, because I had my children rather late and adopting a child demands a lot of energy, a lot of time. We decided I would be 
working part-time and be more available for the children, someone had to be around and I don't feel like it has been a sacrifice» (D345).

\section{Conclusions}

To conclude this brief overview, it seems now to be clear that most of the EU migrant women in Portugal share a negative evaluation of the effects of moving on their employment prospects. Nevertheless it is not easy to make a general assessment of the impact of migration on women's careers and financial autonomy. On the one hand, because these women present many differentiating factors, in terms of their backgrounds and experiences. On the other hand, because family life, particularly having children, still assumes a major role regarding women's "choices", namely referring to job and career.

The research findings presented above evidence the difficulties many EU migrant women have reported in securing stable employment. The fracturing of women's career, as a result of migration, and also of marriage and caring responsibilities as well, leaves many women on the margins of employment. Some have experienced unemployment while others have been forced to accept forms of work, sometimes below their real qualifications, characterised by precariousness, poor working conditions and lack of social protection.

The consequences of partner-determined migration and family formation are thus a decline in economic status and financial autonomy for a larger group of women. These processes particularly affect women who had well-developed professional careers or qualifications prior to their move. A significant number of this group are women whose partners make repeated moves, often working for large multinational companies.

The effects of migration were generally less severe in the group of women who moved motivated by their own careers and personal autonomy. The consequences, in the medium term, were often quite beneficial, with many women being offered new opportunities and taking full advantage of training and education in the host State and utilising their skills to best effect in the domestic labour market. However, marriage and family formation in post-migration period made some of these women experiencing subsequently career dislocation and downward mobility.

To conclude, this paper has evidenced «not only the devastation of many women's professional lives, but also significant periods of re-building. The display of courage and the pioneering qualities exhibited by the women interviewed, irrespective of migration motive, often results in a period of reconstruction in which the sheer tenacity and entrepreneurship of migrant women encourages them to create for themselves new opportunities, either through the grasping of educational and training opportunities or through self-employment. [...] Migrant women are not simply the passive victims of labour market discrimination and gender-role stereotyping, they proved themselves to be capable of utilising their skills in innovative ways, greatly enhancing their financial autonomy and quality of life» (Ackers, 1998: 221). 


\section{References}

ACKERS, Louise (1996). Women, citizenship and European Union law: the gender implications of the free movement provisions. Summary final report to the Equal Opportunities Unit of the European Commission. Plymouth University.

- (1998). Shifting spaces: Women, citizenship and migration within the European Union. Bristol: The Policy Press.

Perista, Heloísa (1998a). «Mulheres em diáspora na União Europeia. Percursos migratórios e trajectórias profissionais e familiares». Revista Crítica de Ciências Sociais, 50, February, p. 153-165.

- (1998b). "Women in Diaspora in the EU: migration, family life and professional trajectories». In Ferreira, V.; TAVAres, T.; PORTUGal, S. Shifting bonds, shifting bounds. Women, mobility and citizenship in Europe. Lisbon: Celta, p. 225-231. PERISTA, Heloísa; MACHADO, Fernando Luís (1997). «Femmes immigrées au Portugal: identités et différences». Migrations-Société, vol. 9, 52, p. 91-103.

PERISTA, Heloísa et al. (1994). Internal migration within the European Union: the presence of women in migration flows and the characteristics of fermale migrants. Portuguese contribution to the interim report of the project Women, citizenship and European Union law: the gender implications of the free movement provisions. Lisbon: CESIS. 